\title{
УПРАВЛІННЯ ОСВІТОЮ ЯК СТРАТЕГІЧНИЙ РЕСУРС: ЗАРУБІЖНИЙ ДОСВІД
}

\author{
Ящук С. П., Журавська Н. С.
}

\section{ВСТУП}

Управління освітою має стати стратегічним ресурсом поліпшення добробуту людей, забезпечення національних інтересів, зміцнення авторитету і конкурентоспроможності держави на міжнародній арені, але, на жаль, значною мірою все ще залишається теоретичною моделлю, а не ефективно впроваджується на практиці. Питанням управління освіти приділялася увага в дослідженнях вітчизняних (Г. Дмитренко, В. Ковальчук, С. Кубіцький, М. Михайліченко, С. Ніколаснко, В. Шинкарук, С. Ящук та ін.) і зарубіжних вчених Ж. Амадо (G. Amado), Ф. Габеран (Ph.Gaberan), М. Гербст (M. Herbst), Ж. Герзінський (J. Herczyński), Е. Гофман (Е. Goffman), К. Доре (C. Doré), А. Левітас (A. Levitas), P. Брізе (R. Brizais), А. Соботка (A. Sobotka) та інші).

Метою дослідження $\epsilon-$ розглянути механізми управління освітою як стратегічним ресурсом, використовуючи зарубіжний досвід. У дослідженні були використані такі теоретичні методи, як аналіз, індукція, дедукція, узагальнення 3 метою виявлення позитивного досвіду управління освітою. Дослідженнями встановлено, що наукові (політичні, економічні, соціальні) засади реформ управління освіти країн Свропи кінця XX - початку XXI ст. $\epsilon$ складником сукупності теоретичних позицій, до якої належать ідеї ліберальної, консервативної та демократичної традицій ${ }^{1}$. Реформування управління освіти - це, зокрема, децентралізація освіти у Польщі, що мала декілька етапів; компетентнісний підхід до підготовки фахівців та зміна триступеневої структури школи у країнах Європейського Союзу. Медіація визначається як акт об'єднання третьою стороною, яка називається «посередником», двох фізичних чи юридичних осіб, які називаються «опосередкованими», на основі правил і засобів, що їх вільно

${ }^{1}$ Ковальчук В.І. Проблеми управлінського лідерства в професійно-технічній освітію. Вісник післядипломної освіти: зб. наук. праць. Вип. 11. Київ: Геопринт. 2009. Ч. 1 C. 101-111. 
приймають, з метою або запобігання спору або його вирішення, або встановлення, або відновлення соціальних відносин ${ }^{2}$.

\section{1. Реформування управління системи освіти в країнах Європейського Союзу}

Реформування управління системи освіти Люксембургу у кінці XX ст. - на початку XXI ст. демонструє не лише значні зміни колишньої триступеневої структури школи, але й те, що вирівнювання різниці між загальною середньою освітою та професійною освітою розширює можливості подальшого навчання молоді у вищих навчальних закладах, в основі яких лежить компетентнісний підхід до підготовки фахівців. Усе це - як державний пріоритет - свідчить про послідовний поступ Великого Герцогства Люксембург у напряму подальшої розбудови високих принципів ідеології Великої Гуманістичної Європи.

Отже, унітарний тип (сильний центр, незначна роль регіональної влади) яскраво представлений в освітніх системах континентального типу (Голландія, Франція, Бельгія, Німеччина, Італія, Люксембург). Федеральний тип (сильний центр, значуща роль регіонів) - наприклад, Австралія. Конфедеративний тип відносин управління (незначна роль центру, провідна роль регіонів) - США (єдиний приклад системи атлантичного типу, в якій у XX ст. не відбулося послідовного одержавлення університетів). У Великобританії політика освітньої експансії набула масштабних форм. Проблема ефективного управління освітніх закладів і одночасно збереження університетської автономії не випадково опинилася у фокусі опису атлантичної моделі. Саме у галузі управління відбулися найістотніші зміни. Не сама по собі експансія освітньої системи, зумовлена демографічними й економічними причинами, перетворила атлантичну модель вищої освіти, а зміни схеми управління, що відбулися за нею ${ }^{3}$. Аналогічно не сам по собі розвиток агентств-посередників, яким держава делегувала свої функції, позбавив атлантичну модель найяскравішої іiі конститутивної межі університетської автономії, а перетворення ефективного менеджменту на ідеологію, менеджеріальну революцію.

2 Ящук С.П. Формування професійно-правової компетентності студентів. Науковий вісник Національного університету біоресурсів і природокористування Украӥни. Сер.: Педагогіка, психологія, філософія. 2016. № 253. С. 333-339.

Кубіцький С.О. Деякі аспекти оцінки якості підготовки конкурентоспроможного фахівця в Україні та за її межами. Київ : НМЦ. 2011. Вип. 27. С. 3-9. 
Досвід децентралізації освіти у Польщі передбачав декілька етапів ${ }^{4}$. Польська система освіти одна 3 децентралізованих в Свропі. Процес децентралізації зайняв тривалий час і розпочався з трансферу до комун дитячих садків у 1990 p. Тоді комунам було передано управління початкових шкіл: у 1993 р. на добровільних засадах та в 1996 р. - на обов'язкових засадах. Процес децентралізації завершився в 1999 році передачею новоствореним повітам середніх та старших навчальних закладів і прийняття у 2000 році поточного алгоритму розподілу субсидій. I вже стільки років школи управляються та фінансуються органами місцевого самоврядування польської місцевої влади та освітянами. До реалій такої ситуації більшість викладачів та посадових осіб місцевої влади звикли. 3 цієї причини в Польщі закон про децентралізацію освіти розвивається, і лише зрідка проходить обговорення основних норм та проблем децентралізації. Однак час від часу державне управління певними школами повертається, зазвичай мотивацією $є$ фінансові проблемами (наприклад, сільських комун) або коли є потреба відсторонити органи самоврядування від особливих рішень у школах (наприклад, Польська спілка вчителів (ZNP) переймає управління школами $)^{5}$.

Обговорення питань децентралізації, включаючи децентралізацію освіти, вказує на переваги прийняття децентралізованої моделі управління i пов'язані 3 цим ризики. Перший аргумент щодо децентралізації освіти стосується педагогічної пропозиції і полягає в тому, що об'єднання розробників політики управління та кінцевих «споживачів» освіти (учнів та їх батьків) дали пропозицію школам адаптуватися до місцевих потреб. Другий аргумент - це демократичний характер децентралізації. Посилення ролі школи та місцевої громади призводить до активізації участі і вчителів, і батьків у функціонуванні освіти i, зрештою, демократичного контролю за освітнім процесом. Третя перевага децентралізованої освіти - це можливість поліпшити розподіл бюджету та використання шкільних ресурсів ${ }^{6}$.

Противники децентралізації освіти також висувають багато серйозних аргументів. Перший - це загроза збільшення нерівності територіальної та соціальної. Якщо муніципалітети та повіти несуть

4 Levitas A. Strategie oświatowe, Biblioteczka Oświaty Samorządowej tom 1, Wydawnictwo ICM UW, Warszawa 2012. S. 23-25.

${ }_{5}$ Шинкарук В.Д. Аспекти українсько-польської співпраці в галузі освіти і науки. Украӥна - Польща: стратегічне партнерство в системі геополітичних координат: матеріали міжнар. наук.-практ. конф. (Київ, 16-17 бер. 2017 р.). Київ, 2017. C. $156-158$.

${ }_{6}$ Herbst M. Finansowanie oświaty, Biblioteczka Oświaty Samorządowej tom 3, Wydawnictwo ICM UW, Warszawa 2012.S. 13-15. 
повну відповідальність за фінансування освіти, також за рахунок власних доходів, можна очікувати зростання різноманітності доступних шкільних ресурсів, зокрема, інвестування в освіту заможних членів громади. Другий важливий аргумент - децентралізація не враховує існування позитиву зовнішніх аспектів виховання, тобто той факт, що користь від хорошої освіти для всього суспільства може бути більшою, ніж вигоди для громади чи групи людей. Це стосується, зокрема, обов'язкової освіти і меншою мірою університетів. У результаті витрати місцевих органів влади на освіту можуть виявитись нижчими від оптимального розподілу 3 погляду суспільства загалом. Протилежного ефекту побоюються ті, хто аналізує збільшення витрат на громадські цілі і як ефект децентралізації влади - витрат державних коштів, не узгоджених із податками. Якщо децентралізовані завдання фінансуються за рахунок участі в податках та за рахунок трансфертів 3 центрального бюджету, то витрати місцевих органів влади зростають швидше ${ }^{7}$.

Також зазначимо, що централізована державна бюрократія може бути менше ефективною, ніж багато незалежних розгалужених апаратів місцевого управління, виконуючи дуже подібні завдання, і підвищений локальний контроль може легко перетворитися на гру інтересів для місцевих бізнесових груп на шкоду школам. Тож критики децентралізації ставлять під сумнів третину цих переваг. Існує також проблема 3 рівнем персоналу управління освітою, особливо в невеликих муніципалітетах та в школах. I останнє, але не менш важливе, бракує переконливих емпіричних досліджень, які підтверджують перевагу децентралізованого управління системи освіти 3 погляду ефективності якості освіти чи отриманих в майбутньому студентами результатів.

Як випливає 3 наведених аргументів, дискусія невирішена. 3 цієї причини рух до децентралізації освіти не $\epsilon$ універсальним чи рівномірним. Децентралізація освіти просунута, наприклад, у Латинській Америці, i набагато слабкіша в африканських країнах. У європейських країнах великий відсоток централізації систем освіти у Франції та Люксембурзі, децентралізовані системи - у скандинавських країнах. Однак за останні двадцять років багато країн провели реформи 3 метою децентралізації освіти, включаючи Україну. Мотивація проведення цих реформ має мало спільного з теоретичними дискусіями про перевагу однієї моделі над іншою, але це як наслідок політичних пріоритетів. Приклад Польщі особливий тим, що відбулася

${ }^{7}$ Herbst M. Decentralizacja oświaty, Biblioteczka Oświaty Samorządowej tom 7, Wydawnictwo ICM UW, Warszawa 2012. S. 8-10. 
децентралізація освіти, як однієї з найважливіших реформ, на самому початку трансформації освіти паралельно із впровадженням демократії та верховенства права, а також радикальними економічними реформами, реалізованими урядом у складі так званого плану професора Бальцеровича (Balcerowicza).

У літературі виділено три рівні децентралізації системи освіти: «відволікання», яке полягає у передачі певних завдань територіально відокремленим відомствам, які безпосередньо звітують перед урядом. Такі офіси у Польщі є інституційно автономними, але здійснюють політику державної освіти під наглядом Міністерства освіти - «шкільні наглядачі» ${ }^{8}$.

Польща здійснила децентралізацію освіти як частину більш широкого процесу децентралізації держави, вмотивованої політичною ситуацією. Як вказано, у Польщі процес децентралізації зайняв тривалий час. Варто додати, що ця «позаосвітня» мотивація до децентралізації освіти не характерна лише для країн, що трансформують політичні системи. Дослідник Е. Фіске (Е. Fiske) стверджує, що децентралізація за визначенням $є$ процесом політичним ${ }^{9}$.

\section{2. Реформування управління освітніх проектів у Соціальних школах Франції}

Перш ніж відповісти на виклики щодо реформування управління освітніх проектів, зокрема, у Соціальних школах Франції, важливо визначити, що таке освітній проект. «Освітній проект - це не гаджет, це дизайн, розроблений разом: «Я» та «Інший», який дає змогу останньому знайти чи знову відкрити сенс у своєму житті через усі ці крихітні дії, що становлять повсякденну реальність. Саме в цьому сенсі проект грунтується на злагоджених амбіціях, оскільки всі ці дії, що визначаються у висновку, становлять основу досліджень» ${ }^{10}$.

Зауважимо, що проект складається 3 різних етапів, які необхідно виконати протягом певного часу: етап розробки проекту, етап реалізації та, нарешті, етап оцінки. Для вихователя (спеціалізований викладач) проект створений для досягнення мети: розуміння та застосування

8 Levitas A. Strategie oświatowe, Biblioteczka Oświaty Samorządowej tom 1, Wydawnictwo ICM UW, Warszawa 2012. S. 3-6.

${ }_{9}^{9}$ Шинкарук В.Д. Аспекти українсько-польської співпраці в галузі освіти і науки. Україна - Польща: стратегічне партнерство в системі геополітичних координат : матеріали міжнар. наук.-практ. конф. (Київ, 16-17 бер. 2017 р.). Київ, 2017. C. $156-158$.

${ }^{10}$ Amado G., Fustier P., Ravon B.. Refaire parler le métier. Le travail pluridisciplinaire : réflexivité, controverses, accordage In Nouvelle revue de psychosociologie 2012/2 (n $\left.{ }^{\circ} 14\right)$ : Faire Equipe (en ligne). Erès. P. 97. 
щоденних правил. Зрештою, це азарт, коли вихователь та користувач (вихованець) прагнуть до перемоги. Ось чому вихователь повинен нести відповідальність за проект і належним чином контролювати його за допомогою відповідних інструментів.

Для здійснення освітнього проекту важливо створити посередництво. Визначимося 3 поняттям «посередництво». «Медіація визначається як акт об'єднання третьою стороною, яка називається «посередником», двох фізичних чи юридичних осіб, які називаються «опосередкованими», на основі правил і засобів, що їх вільно приймають, з метою або запобігання спору або його вирішення, або встановлення, або відновлення соціальних відносин» ${ }^{11}$.

Підкреслимо, що термін «медіація» склався навколо ряду галузей, таких як освіта та управління. Це новий термін і він з'явився через інформаційну та комунікаційну галузі, а потім поширився на освітянську аудиторію. Питання про медіацію зазвичай виникає як для дорослих, так і для дітей поза школою. У медіації вихователь займає місце посередника, а користувач - місце опосередкованого. Вихователь повинен буде маніпулювати посередництвом за своїм вибором (у нашому випадку - спортивним посередництвом), щоб мати можливість застосувати його до користувача (рис. 1).

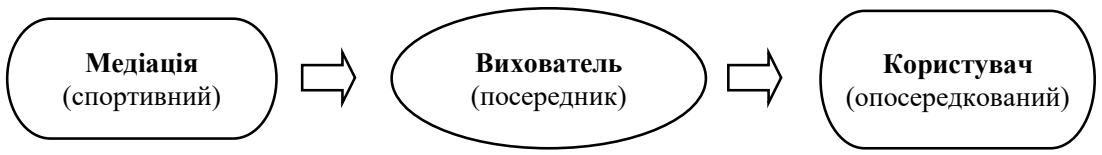

Рис. 1. Схема процесу медіації

Отже, медіатор - це центральна фігура медіації, яка сприяє ефективності медіаційного процесу. Він передає основні речі користувачеві опосередковано.

Передусым доцільно зазначити в цій частині дослідження, що 3 початком освітнього проекту спеціалізований викладач завжди має бути на зв'язку зі всіма членами багатопрофільної команди, бо важливо усвідомити важливість обміну думками під час роботи в команді. Освітній проект під час стажування в Соціальній школі м. Бордо (Франція) з підлітками, зокрема, умовно названою Софією, дозволив бути ближчим до інституційного порядку. Різні формальні чи неофіційні зустрічі з професіоналами, зокрема багатодисциплінарною командою (l'équipe pluridisciplinaire) соціальної школи, дозволили

11 Ящук С.П. Формування професійно-правової компетентності студентів. Науковий вісник Наиіонального університету біоресурсів і природокористування України. Сер.: Педагогіка, психологія, філософія. 2016. № 253. С. 333. 
вдосконалити своє мислення. Це також змусило уточнити поставлений раніше клінічний прогноз вихованця, а також свої цілі та дії як спеціалізованого викладача.

Отже, щоб проаналізувати цю ситуацію, доцільно було звернутися до багатодисциплінарної команди та уточнити клінічну картину, зокрема: Софія приховує багато почуттів смутку, сорому та, можливо, навіть гніву до матері: іiї минулих дій в моральному аспекті. Сором може вторгнутись в існування людини, це за визначенням, як одкровення чогось, що ми хочемо зберегти, приховати. Сором особливо присутній у підлітковому віці. Підлітки можуть соромитися, наприклад, свого тіла, за всі зміни, які відбуваються з ними, але можуть також соромитися своїх батьків, свого образу. На думку психолога Патріка Енджі Рауль (Р.-A. Raoult), сором - це почуття «жити в злому під поглядом іншого; бути голим» ${ }^{12}$.

За визначенням вченого Е. Гофмана (E. Goffman), стигматизований індивід - це «індивід, якого легко можна було б помістити до кола звичайних суспільних відносин, має таку характеристику, що може бути нав'язана увазі тих із нас, хто зустрітися і відвернутися від нього, тим самим знищуючи його права на нас через інші його атрибути. У нього стигма, дратівлива відмінність від того, що ми очікували» ${ }^{13}$.

Водночас сором змушує хотіти зникнути, сховатися під землею, щоб уникнути погляду інших. Софія, мабуть, соромиться образу своєї матері. Вона пережила речі, які їй зашкодили, і вона ніколи не могла розповісти про всі емоції, які в неї були. Дитиною вона соромилася свого батька через аморальну поведінку матері. Це сором - бути дитиною винного дорослого, який не визнає себе таким i який відмовляється виправляти помилки. Це тому, що дорослий не соромиться і не знає як або не хоче виправити свою провину. Тому дитина соромиться, поки сама не відчує себе виною за вину батька або матері. Сором змушує суб'єкта зіткнутися з виною, якої він хотів би уникнути. Сором, який відчувала Софія, поступово затьмарював іiі образ, який вона мала про себе та про свою впевненість у собі. Психолог Патрік Анже Рауль (P.-A. Raoult) каже у своїй книзі «Сором у підлітковому віці», що «сором знаменує невдачу самооцінки. Вона також вирішує нарцисичну проблему (la revalorisation narcissique)» ${ }^{14}$. Дійсно, помітна відсутність самооцінки у Софії.

${ }^{12}$ Brizais R. La fonction éducative : Entre intervention directe et indirecte, entre sujet et institution. (en ligne). Empan 2012/1 ( $\left.{ }^{\circ} 85\right)$ ). P. 19.

${ }^{13}$ Gaberan Ph. Cents mots pour être éducateur : Dictionnaire pratique du quotidien. Erès, 2009. P. 17.

${ }^{14}$ Brizais R. La fonction éducative : Entre intervention directe et indirecte, entre sujet et institution. (en ligne). Empan 2012/1 (n॰85). P. 21. 
Ми можемо кваліфікувати самооцінку як образ, який ми бачимо в дзеркалі. Справа не тільки в тому, як ми бачимо себе, але і в тому, як почуваємося. Дуже важливо мати певну самооцінку, оскільки саме це дозволяє нам бачити власну цінність. За словами Селон Кулі (S. Cooley) самооцінка формується 3 народження i завдяки усім соціальним взаємодіям, які ми маємо в житті ${ }^{15}$. За словами психологів багатодисциплінарної команди соціальної школи, 3 яким довелося неодноразово спілкувався, Софія будувала бачення себе навколо важких періодів свого дитинства: розлука з батьками, аморальна діяльність матері, свідком якої була молода дівчина, глузування в школі. Ховаючи в собі цей сором, Софія змінила свій захисний механізм, щоб мати можливість жити 3 цим соромом. Це суто психічний процес, який має на меті захистити наш мозок від поганих емоцій. Захисний механізм у разы з Софією - це нехтування гігієною тіла, здоровим харчуванням, заняттям спортом. Софія боїться стати подібною до своєї матері, вона боїться, що ії тіло приверне до себе увагу чоловіків. I вона використовує своє тіло як захист від зовнішнього світу. Чим більше іï організм буде занедбаний, тим менше вона буде стикатися з зовнішніми проблемами і тим менше вона буде «кидатися в очі», хоча захисні реакції допомагають жити з соромом, а не виходити з нього.

Важливим етапом управління освітнім проектом $\epsilon$ визначення загальних та оперативних цілей (рис. 2). Отже, для належного виконання проекту важливо визначити показники, за допомогою яких відзначається прогрес проекту, а потім оцінити його. Людина, яка не має впевненості в собі, скоріше відмовиться від боротьби за поставлені цілі, як у групі однолітків, так і в своїй майбутній парі, думаючи, що «я, як людина, нецікава для оточуючих».

Ось чому спеціалізовані педагоги (вихователі, соціальні працівники) повинні наполягати на особистому успіху підлітків, щоб мати можливість розвивати цю самооцінку, адже саме це дозволяє людині нарешті мати достатньо сміливості, щоб протистояти складним етапам в житті. Зокрема, вплив спортивного посередництва дозволив Софії виділити свої успіхи. Для педагогів також важливо імплементувати позитивну поведінку досліджуваного в якість особистості, яку потрібно підкріпити, зокрема, нарцистичну переоцінку (la revalorisation narcissique).

Інакше, ця людина «стає дуже маленькою», сподіваючись залишитися непоміченою ${ }^{16}$.

${ }^{15}$ Gaberan $\mathrm{Ph}$. Cents mots pour être éducateur : Dictionnaire pratique du quotidien. Erès, 2009. P. 31.

${ }^{16}$ Brizais R. La fonction éducative : Entre intervention directe et indirecte, entre sujet et institution. (en ligne). Empan 2012/1 (n85). P. 21. 


\begin{tabular}{|c|c|}
\hline $\begin{array}{l}\text { Загальні цілі (Objectifs généraux) } \\
\text { Отримати краще уявлення про ceбе } \\
\text { (Avoir une meilleure image d'elle- } \\
\text { même) } \\
\text { Доступ до добробуту } \\
\text { (Accéder à un mieux-être) } \\
\text { (фізичного та психічного) } \\
\text { (physique et psychique) }\end{array}$ & $\begin{array}{l}\text { Оперативні цілі } \\
\text { (Оbjectifs оре́rationnels ) } \\
\text { Насолоджуйтесь активністю } \\
\text { (Se défouler, prendre du plaisir à } \\
\text { l'activité) } \\
\text { Пишайтеся собою і своїми здібнос- } \\
\text { тями, відчувайте себе гідними } \\
\text { прихильності } \\
\text { (Être fière d'elle et de ses capacités, } \\
\text { se sentir digne d'affection) }\end{array}$ \\
\hline $\begin{array}{l}\text { Подбати про своє тіло (Prendre soin } \\
\text { de son corps ) }\end{array}$ & $\begin{array}{l}\text { Зверніть увагу на свій зовнішній } \\
\text { вигляд } \\
\text { (Faire attention à son apparence) }\end{array}$ \\
\hline & $\begin{array}{l}\text { Доглядайте за своїм тілом } \\
\text { (Valoriser son corps) } \\
\text { Поліпшіть гігієну } \\
\text { (Améliorer son hygiène) }\end{array}$ \\
\hline
\end{tabular}

\section{Рис. 2. Загальні та оперативні цілі}

Самооцінку можна визначити як навичку, оскільки їі можна покращити, працюючи над нею. Введення спортивної діяльності в цьому проекті як посередництва було важливим, щоб реалізувати головну мету - підняти самооцінку. Досі Софія відмовлялася виконувати ті завдання, в яких вона отримувала поразку, вона не мала впевненості в собі знову ризикнути і здавалася при першій невдачі. Наприклад, від першого сеансу цього освітнього проекту вона могла б відмовитися, якби не пройшла «примусові кола» під час роботи 3 психологами багатодисциплінарної команди (l'équipe pluridisciplinaire). «Повторення сценаріїв фізичних навантажень дозволяє нам працювати над м'язовими зусиллями та над відчуттям, яке його супроводжує» ${ }^{17}$.

Спорт також дав можливість Софії прогресувати. Ми в суспільстві, де сильно покладаємось на результати. Наприклад, у школі учнів зазвичай оцінюють за оцінкою, а не за прогресом, який вони отримали протягом року. Оскільки у Софії також були труднощі в школі, було запропоновано спорт як посередництво, бо спорт є цікавим способом підкреслити прогрес, а не результат. Хоча слід також зазначити, що прогрес не завжди присутній у спорті. Існують фази застою, коли з фізичних чи психологічних причин ми не можемо досягти результату.

${ }^{17}$ Gaberan $\mathrm{Ph}$. Cents mots pour être éducateur : Dictionnaire pratique du quotidien. Erès, 2009. P.76. 


\section{3. Система оцінювання в управлінні освітніми проектами}

Перш ніж оцінювати освітній проект, важливо зрозуміти природу оцінювання проекту. Якщо ми посилаємось на визначення Моріса Капула (M. Capul) та Мішеля Лемая (M. Lemay), то оцінка буде «читанням реальності, інструментом для підбору підсумків тієї чи іншої роботи». Йдеться про визначення відповідності цілей та ступеня їх досягнення, ефективності розвитку, ефективності впливу та стійкості» ${ }^{18}$. Отже, це дозволяє нам побачити, які поставлені цілі на початку проекту вже виконані. Для проведення цієї оцінки необхідно базуватись на критеріях, які є орієнтирами успішності проекту, та, можливо, необхідності його коригування ${ }^{19}$.

За словами Філіппа Чавароче (Р. Chavaroche ): «Будь-яка діяльність повинна бути частиною систематичного оцінювання. Це означає регулярний аналіз того, що відбувається під час спостережень за роботою професіоналів, які втручаються в освітній процес. Крім того, оцінка є об'єктивнішою 3 порадами інших фахівців. Протягом посередництва доцільно обмінюватися думками 3 усіма членами команди та враховувати їх коментарі.

Отже, центральним етапом освітнього проекту $є$ розробка системи його оцінювання. Для того щоб ефективно оцінити етапи освітнього проекту, була створена та використана оціночна сітка деталізації критеріїв, на яких грунтувалося дослідження:

- оцінка узгодженості, цінності проекту: перевірити чи досягаються оперативні цілі чи можливо вони досягнуті; перевірити чи виконані оперативні дії, пов'язані 3 ціллю, заявленою на початку проекту: нарцистичною переоцінкою (la revalorisation narcissique) Coфiï;

- оцінка показників: відзначити хід проекту та його оцінку за визначеними критеріями;

- оцінка засобів та ресурсів: оцінка ресурсів, які були використані для організації проекту;

- оцінка впливу цього проекту на ціннісні дії: виконання дій, які відповідали б реальним потребам Софії, зокрема, оцінка спортивного посередництва як нарцисичного інструменту переоцінки (la revalorisation narcissique).

На додаток до цієї оцінки доцільно врахувати думку та почуття Софії. Слід додати, що під час цього проекту, заснованого на спостереженнях та висновках, інтегруючись, максимально враховані побажання і потреби Софії.

${ }^{18}$ Amado G., Fustier P., Ravon B.. Refaire parler le métier. Le travail pluridisciplinaire : réflexivité, controverses, accordage In Nouvelle revue de psychosociologie 2012/2 (n $\left.{ }^{\circ} 14\right)$ : Faire Equipe (en ligne). Erès. P. 98.

19 Журавська Н.С. Організація самостійної роботи студентів сільгосптехнікумів (на матеріалах предметів агрономічного циклу). Київ : НАУ. 1995. С. 19. 
Інструменти оцінювання:

а) журнал, в якому зазначена вся еволюція освітнього проекту, зокрема, враження від підлітка (умовно Софія) після курсу семінарів із професіоналами багатодисциплінарної команди МЕКС (l'équipe pluridisciplinaire);

б) сітка оцінювання: грунтуючись на спостереженнях під час сесій $\mathrm{i}$ рекомендацій багатодисциплінарної команди та журналу «еволюції проекту», де оцінюються здобутки, виконання оперативних і загальних цілей Софії.

Показники оцінки:

- приїжджайте вчасно;

- дотримуйтесь усіх етапів проекту та їх ієрархії;

- беріть регулярно участь у заходах, будьте присутні на всіх сесіях;

- майте позитивні коментарі щодо своїх дій, посміхайтеся під час заняття;

- починайте говорити i, можливо, висловите почуття.

Для здійснення спортивного посередництва довелося використовувати певні ресурси та мати доступ до обладнання, необхідного для налаштування спортивних занять. Ще одним важливим елементом було те, що Софія насолоджувалася запропонованими спортивними заняттями та безпосередньою участю у них. У 1997 р. Ю. Оммундсен (Y. Ommundsen), професор спорту та психічного здоров'я Норвезької школи спортивних наук (professeur en sport et santé mentale à l'école norvégienne des sciences du sport) та П. Ваглум (P. Vaglum), лікар, психіатр та професор університету в Осло (médecin, psychiatre et professeur à l'Université d'Oslo) провели дослідження серед 223 молодих футболістів віком від 12 до 16 років ${ }^{20}$. Це дослідження «показує, що вплив сприйнятої компетентності у футболі на самооцінку в цьому виді спорту залежав від важливості для суб'єктів компетентності у футболі: чим більше гравців відчували, що футбол був важливою діяльністю у їхньому житті, тим більше їх сприйняття компетентності піднімало їх самооцінку (рис. 3).

I навпаки, почуття компетентності гравців, які не вважали цю діяльність важливою, було мало пов'язане 3 їх самооцінкою». Статистичний аналіз цих серій показав, що самооцінку не можна вважати стійкою рисою особистості з часом». Це дослідження показує, що самооцінка постійно змінюється. Однак це не універсальне уявлення.

${ }^{20}$ Gaberan $\mathrm{Ph}$. Cents mots pour être éducateur : Dictionnaire pratique du quotidien. Erès, 2009. P. 78. 


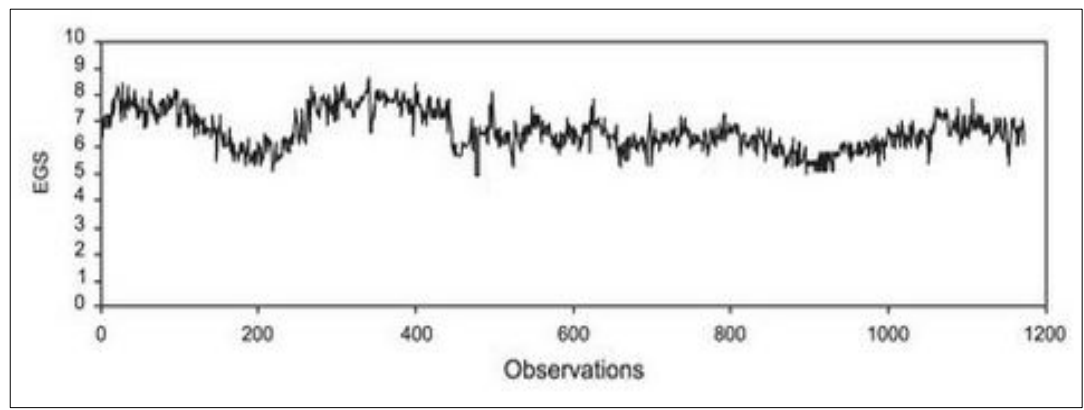

Рис. 3. Еволюція самооцінки у нормального суб'скта протягом двадцяти місяців

Наступний малюнок (рис. 4) ілюструє еволюцію самооцінки протягом 67 днів у пораненого високопродуктивного спортсмена. Відзначимо, що «значні зміни можуть відбуватися щодня, від найнижчих рівнів (депресія) до найвищих рівнів (ейфорія). Ця динаміка здається насправді повністю керованою життєвими подіями, без жодної логіки самозбереження». Тому самоццінка може бути змінена зовнішніми елементами, що унеможливлює постійну самооцінку.

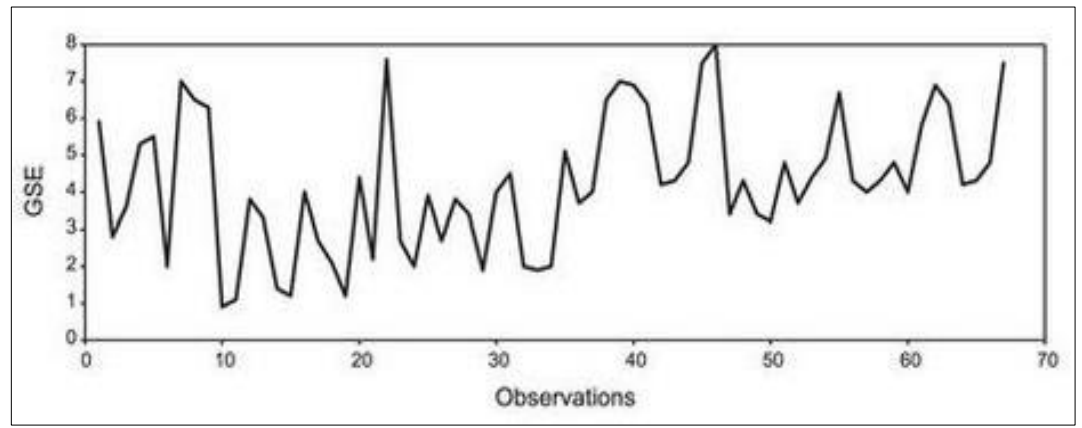

Рис. 4. Еволюція самооцінки у травмованого спортсмена за період 67 днів

Спорт - це «освітнє середовище для інвестування» ${ }^{21}$. Отже, насамперед для того щоб упорядкувати юного підлітка для занять спортом, соціальна школа надає спеціалізованому викладачу необхідну суму для придбання спортивного одягу, як для бігу, так і для боксу.

Що стосується середовища для бігу, то було запропоновано скористатися парком, розташованим поблизу соціальної школи; що

${ }^{21}$ Gaberan $\mathrm{Ph}$. Cents mots pour être éducateur : Dictionnaire pratique du quotidien. Erès, 2009. P. 72. 
стосується практики боксу - спортивним залом у складі соціальної школи, який вже був обладнаний необхідними приладдями: боксерські рукавички, мішок для перфорації (після запиту, який надійшов від спеціалізованого педагога до керівництва соціальної школи, було надано дозвіл на заняття у цьому приміщенні для практики боксу).

Нарешті, соціальна школа погодилася фінансувати реєстрацію Софії на боксерський клуб. Вона не приєдналася до початку року, але це не було проблемою для соціальної школи, яка також забезпечила для реалізації освітнього проекту необхідний бюджет для занять спортом Софії у спортивному клубі.

Саме наприкінці стажування в Соціальній школі Бордо був запроваджений цей освітній проект, тому важливо було подумати про його наступність. Адже освітній проект був спрямований на нарцисичну переоцінку Софії і $€$ довгостроковим проектом. Софії потрібна постійна i регулярна діяльність для того щоб досягти результату у піднятті самооцінки. Під час дебатів між професіоналами багатодисциплінарної команди соціальної школи було визначено два можливі варіанти: 3 одного боку, була можливість у одного 3 професіоналів взяти на себе зобов'язання і продовжувати спортивне посередництво з Софією, а з іншого - можливість зареєструвати Софію у спортивний клуб, зокрема, боксу, неподалеку від соціальної школи, щоб вона могла продовжувати діяльність «самостійно». Дівчина хотіла продовжувати займатися саме цією дисципліною, щоб прогресувати. Про зміну ії діяльності не велося. «Індивід прагне перевершити те, що він цінує, і він цінує те, в чому він вищий» ${ }^{22}$.

Зауважимо, що вибір між двома можливостями був вирішальним для навчального колективу. Софія починала худнути, приділяючи набагато більше уваги своєму харчуванню та гігієні тіла, тому нам довелося знайти найбільш підходяще рішення для дівчини. Менеджер соціальної школи нарешті дозволив мені вирішити майбутнє проекту, як людині, яка керувала цим проектом із самого початку. Через деякий час Софія прийшла поговорити, щоб повідомити про своє рішення: вона подякувала за те, що iї навчили основам боксу i сказала, що іï може зацікавити сесія в боксерському клубі. Після іiі рішення почався пошук боксерського клубу, який би привітав Софію на тестовому засіданні. Нам пощастило знайти клуб територіально близько біля соціальної школи. Нам також вдалося встановити тестову сесію, до якої супроводжували Софію. Дівчина побоювалася рівня інших підлітків і сказала, що хоче показати себе якнайкраще.

\footnotetext{
${ }^{22}$ Brizais R. La fonction éducative : Entre intervention directe et indirecte, entre sujet et institution. (en ligne). Empan 2012/1 (n $\left.{ }^{\circ} 85\right)$ ). P. 22.
} 
Завдання спеціалізованого викладача заспокоїти молоду дівчину, сказавши їй, що вона вже зрозуміла основи боксу i, що тепер їй залишається лише відкритися до нового навчання, щоб мати можливість прогресувати. Тестова сесія пройшла у чудовій атмосфері, Софію оточили інші дівчата-підлітки, аудиторія була повністю жіноча. 3 неї не глузували. Тренер цього клубу зазначив, що ентузіазм Софії запевнив його, що в цьому клубі у неї буде хороша групова динаміка. Софію записали до боксерського клубу; вона досить вмотивована та впевнена у своєму виборі виду спорту.

Отже, висловлення різних думок $є$ звичною практикою в установах $\mathrm{i}$ $\epsilon$ необхідною для належного функціонування командної роботи в управління освітніми проектами. Зазначимо, що в команді професіонали 3 різним досвідом, тому природно мають унікальні уявлення 3 управління проектом і $\epsilon$ джерелом різноманітного бачення вирішення проблеми. Найефективніші рішення з'являються завдяки вираженню відповідних поглядів. Професор психології праці в Національному центрі мистецтв та ремесел (CNAM) I. Клот (Y. Clot) зауважив: «Єдиною доброю практикою, безперечно, $€$ практика професійної суперечки між експертами, а потім між ними за ієрархічною лінією, навіть за стінами компанії. Суперечка не повинна сприйматися тут у значенні суперечок між людьми, а розбіжностей щодо критеріїв якості навчальної дії. За умови, що у кожного є місце та час вислухати, викласти свої аргументи та почути аргументи інших» ${ }^{23}$.

\section{ВИСНОВКИ}

Враховуючи викладене, можна зробити висновок, що в управлінні системи освіти важливе місце займають методологічні підходи та принципи. $\mathrm{y}$ неоліберальній складовій освітньо-політичного консенсусу у глобальному масштабі країн Європейського Союзу такими принципами $\epsilon$ : принципи високої ефективності і продуктивної діяльності освітньої системи (пріоритетний економічний детермінізм цілей) та вільного вибору освітніх послуг (ідея ринкового вибору); у консервативному складнику - принципи збереження традиційних цінностей (пріоритетний етичний детермінізм цілей), вільного вибору освітніх послуг (ідея ринкового вибору) та високої ефективності діяльності освітньої системи; у демократичному складнику - принципи соціальної справедливості (пріоритетний соціальний детермінізм цілей), удосконалення діяльності освітньої системи та вільного вибору

${ }^{23}$ Agence nationale pour l'amelioration des conditions de travail. Le travail peut-il devenir supportable ? Entretien avec Yves Clot et Michel Gollac. (en ligne). Publié le 13.10.2014. 
освітніх послуг (ідея демократичного вибору). Зміни в системі освіти, запроваджені в 90-х роках минулого століття, повністю вплинули на організацію освітнього процесу, структуру шкіл та їх манеру функціонування, матеріальну базу. Зокрема, польська освіта вступила в нову еру вже як повністю децентралізована сфера, але коли йдеться про початкові школи та дитячі садки.

Отже, журнал клінічного дослідження дозволяє спеціалізованому педагогу усвідомити важливість роботи в команді та необхідність встановлення ефективної комунікації між усіма членами багатопрофільної команди; інтегрувати поняття формальної та неформальної комунікації, які будуть корисні протягом усієї кар'єри; суперечка щодо клінічної картини підопічного та вибір, як посередництва, певного освітнього курсу може бути ефективними під час колективної роботи. Для кращої узгодженості навчального втручання кожен педагог повинен поділитися своїми міркуваннями, своїми ідеями, вміти довіряти своїм колегам. Саме завдяки обміну думками можна досягти спільної мети, навіть якщо думки відрізняються від початку. У ситуації, що склалася, командна робота виявилася важливою для пошуку рішення, адаптованого до проблеми молодої дівчини.

Перспективи подальших досліджень вважаємо доцільним спрямувати на пошук шляхів впровадження окреслених управлінських здобутків у країнах Свропейського Союзу, у професійну підготовку майбутніх управлінців та соціальних працівників в Україні.

\section{АНОТАЦІЯ}

У науковому дослідженні проблема управління освітою як стратегічним ресурсом - одна з проблем імплементації зарубіжного досвіду у освітній процес закладів вищої освіти України. Завдяки активізації процесів політичної, економічної та культурної глобалізації країн Європейського Союзу відбувається поширення неоліберального освітньо-політичного консенсусу у глобальному масштабі, що призвело до появи феномену, який можна назвати глобалізацією освіти. Автори розглянули процес децентралізації освіти у Польщі

За останні два десятиліття: перший етап (1990-2000) - період тиску, створення управління системи освіти, яка кардинально відрізнялася від державної. Протягом другого десятиліття (2000-2010рр.), яке можна визначити як період низької стабілізації, система управління освіти стабілізувалася, органи місцевого самоврядування адаптувалися до нових завдань та впровадження нових механізмів оцінювання та нагляду, зокрема системи зовнішніх іспитів та зовнішнього оцінювання. Автори розглянули процес управління соціальними 
освітніми проектами у Соціальних школах Франції. Підкреслено, що проект складається з певних етапів: розробки, реалізації та оцінки. Центральним етапом освітнього проекту $є$ розробка системи його оцінювання; для ефективної оцінки етапів освітнього проекту створена та використана оціночна сітка деталізації критеріїв, на яких грунтувалося дослідження. Зазначено, що спеціалізований викладач (вихователь, соціальний працівник) повинен нести відповідальність за проект $\mathrm{i}$ належним чином його контролювати за допомогою відповідних інструментів. Наголошено, що для ефективного управління соціальним проектом, необхідно акцентувати увагу на посередництві, зокрема спорті, який має освітній та виховний ефект; у медіації вихователь займає місце посередника, а користувач (вихованець) місце опосередкованого.

\section{ЛІТЕРАТУРА}

1. Журавська Н.С. Організація самостійної роботи студентів сільгосптехнікумів (на матеріалах предметів агрономічного циклу). Київ : НАУ. 1995. 24 с.

2. Ковальчук B.I. Проблеми управлінського лідерства в професійнотехнічній освіті. Вісник післядипломної освіти: зб. наук. пращь. Вип. 11 / голов. ред. В.В. Олійник. Київ : Геопринт, 2009. Ч. 1 С. 101-111.

3. Кубіцький С.О. Деякі аспекти оцінки якості підготовки конкурентоспроможного фахівця в Україні та за ії межами. Київ : НМЦ. 2011. Вип. 27. С. 3-9.

4. Шинкарук В.Д. Аспекти українсько-польської співпраці в галузі освіти і науки. Украӥна - Польща: стратегічне партнерство в системі геополітичних координат: матеріали міжнар. наук.-практ. конф. (Київ, 16-17 бер. 2017 р.). Київ, 2017. С. 156-158.

5. Ящук С.П. Формування професійно-правової компетентності студентів. Науковий вісник Національного університету біоресурсів $i$ природокористування України. Сер.: Педагогіка, психологія, філософія. 2016. № 253. C. 333-339.

6. Agence nationale pour l'amelioration des conditions de travail. Le travail peut-il devenir supportable ? Entretien avec Yves Clot et Michel Gollac. (en ligne). Publié le 13.10.2014. (Consulté le 10.01.2020). URL: https://www.anact.fr/le-travail-peut-il-devenir-supportable-entretien-avecyves-clot-et-michel-gollac.

7. Amado G., Fustier P., Ravon B.. Refaire parler le métier. Le travail pluridisciplinaire : réflexivité, controverses, accordage In Nouvelle revue de psychosociologie 2012/2 ( $\left.n^{\circ} 14\right)$ : Faire Equipe (en ligne). Erès. Pages 97 à 111. (Consulté le 15.11.2019). URL: https://www.cairn.info/revue-nouvellerevue-de-psychosociologie-2012-2-page-97.htm. 
8. Brizais R. La fonction éducative : Entre intervention directe et indirecte, entre sujet et institution. (en ligne). Empan 2012/1 (n $\left.{ }^{\circ} 85\right)$ pages 19 à 26. (Consulté le 06.12.2019). Disponible sur : https://www.cairn.info/ revue-empan-2012-1-page-19.htm

9. Gaberan $\mathrm{Ph}$. Cents mots pour être éducateur : Dictionnaire pratique $d u$ quotidien. Erès, 2009. 160p (Trames)

10. Levitas A. Strategie oświatowe, Biblioteczka Oświaty Samorządowej tom 1, Wydawnictwo ICM UW, Warszawa 2012

11. Herbst M. Finansowanie oświaty, Biblioteczka Oświaty Samorządowej tom 3, Wydawnictwo ICM UW, Warszawa 2012.

12. Herbst M. Decentralizacja oświaty, Biblioteczka Oświaty Samorządowej tom 7, Wydawnictwo ICM UW, Warszawa 2012. URL: http://www.euroreg.uw.edu.pl/dane/web_euroreg_publications_files/2175/he rbst_2012_decentralizacja_oswiaty.pdf.

\section{Information about the authors:} Yashchuk S. P., Ph.D. in Pedagogic Sciences, Intern in Regional Institute of Social Work Aquitaine, Bordeaux (France) National University of Life and Environmental Sciences of Ukraine 15, Heroes of Defense str., Kiev, Ukraine

Zhuravska N. S., Doctor of Pedagogical Sciences,

Professor at the Department of Management and Educational Technologies National University of Life and Environmental Sciences of Ukraine 15, Heroes of Defense str., Kiev, Ukraine 